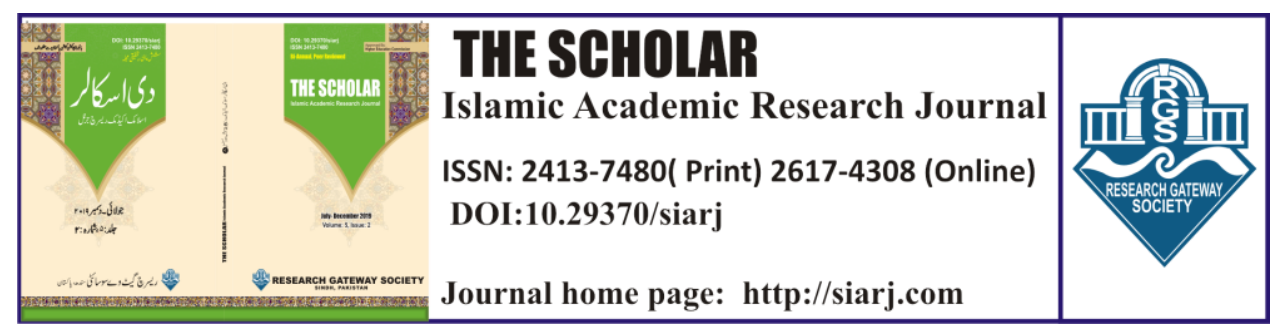

ISLAMOPHOBIA IN GERMANY: A CASE STUDY OF PEGIDA

\section{Nauman Sial}

Research Associate/Ph.D. Scholar in

Media and Communication Studies.

Islamic University (IIU), Islamabad,

Pakistan.

Email: naumansial@hotmail.com

ORCID IID:

https://orcid.org/0000-0002-3232-462X

\section{Yasar Arafat}

Research Associate/Ph.D. Scholar in Media and Communication Studies, Islamic University (IIU), Islamabad, Pakistan.

Email: yasar2010@yahoo.com

\section{ORCID IID:}

https://orcid.org/0000-0001-9038-0171

To cite this article:

Sial, Nauman, Abid Zafar, and Yasar Arafat. "ISLAMOPHOBIA IN GERMANY: A CASE STUDY OF PEGIDA.” The Scholar-Islamic Academic Research Journal 5, No. 2 (December 16, 2019) : 164-189

To link to this article: https://doi.org/10.29370/siarj/issue9ar15

\begin{tabular}{|c|c|}
\hline Journal & $\begin{array}{l}\text { The Scholar Islamic Academic Research Journal } \\
\text { Vol. 5, No. } 2 \text { || July -December 2019||P.164-189 }\end{array}$ \\
\hline Publisher & Research Gateway Society \\
\hline DOI: & $\underline{10.29370 / \text { siari/issue9ar15 }}$ \\
\hline$\overline{\text { URL: }}$ & https://doi.org/10.29370/siari/issue9ar15 \\
\hline License: & Copyright c 2017 NC-SA 4.0 \\
\hline Journal homepage & www.siarj.com \\
\hline Published online: & $2019-16-12$ \\
\hline
\end{tabular}

2. Abid Zafar

Freelance Researcher/M.S. in Media and Communication Studies, Pakistan Email: aabidzafarwarraich@gmail.com ORCIID IID:

https://orcid.org/0000-0002-1079-8250
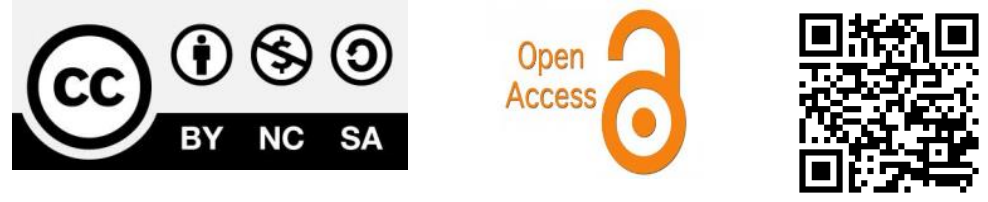
THE SCHOLAR (July - December 2019)

\title{
ISLAMOPHOBIA IN GERMANY: A CASE STUDY OF PEGIDA
}

\author{
Nauman Sial, Abid Zafar, Yasar Arafat
}

\begin{abstract}
:
After the event of 9/11 in New York, Muslim countries have been affected badly with the ongoing war on terror. Muslim population which was affected due to this war, they started to move to other nation states. Most of the populations from war affected areas migrated to the Western countries. More than one million immigrants and refugees had arrived in Germany in the year 2015, and the registered refugees from top three countries of the origins were from Syria, Afghanistan and Iraq respectively. On the other hand, Islamophobia started to reflect in Germany with the rise of anti-Islamic and anti-Muslim movements. This research has observed the different events in Germany that could be taken as Islamophobic instances. Patriotic Europeans against the Islamisation of the West (PEGIDA) has been examined as a case study for this research work. The data has been collected through secondary sources. The study revealed that due to this movement, the violent attacks have been progressively increased on refugee accommodations and their worships. It has been concluded that the movement of PEGIDA is responsible not only for the discursive violence but it is also responsible for the interpersonal violence against the Muslim refugees in Germany.
\end{abstract}

KEYWORDS: Islamophobia, Germany, PEGIDA, Muslim Refugees, Anti-Islam 


\section{INTRODUCTION:}

Migration is an integral part of the evolution of human race, the causes of which range from war and economic disparity to advances in information technology and economic migration. ${ }^{1}$ The ongoing war on terror has badly affected the Muslim countries, and their population migrated to other countries due to this war. Most of the Muslim populations migrated to the Western countries. The Federal Office for Migration and Refugees ${ }^{2}$ had reported that more than one million immigrants and refugees had arrived in Germany in the year 2015. The top three countries of the origins who had registered between the months of January and December 2015 were from Syria, Afghanistan and Iraq respectively. ${ }^{3}$ In Germany, reports switch among reporting a 'flood', a 'migrant crisis' or a 'refugee crisis.' ${ }^{4}$ This research focuses on the different events in Germany that could be taken as Islamophobic instances along with the rise of anti-Muslim and anti-Islamic movement in Germany i.e. Patriotic Europeans Against the Islamisation of the West (PEGIDA) that came into existence in the year 2014.

${ }^{1}$ Rudmin, Floyd W. "Critical History of the Acculturation Psychology of Assimilation, Separation, Integration, and Marginalization." Review of General Psychology, 2003: 3-37.

${ }^{2}$ EASY (Erstverteilung der Asylsuchenden) transl. Initial Distribution of Asylum Seekers is the system of the BAMF (Bundesamt für Migration und Flüchtlinge) transl. Federal Office for Migration and Refugees; BAMF. (2017, January 1). BAMF: EASY. Retrieved March 31, 2017, from BAMF: http://www.bamf.de/DE/Fluechtlingsschutz/AblaufAsylv/Erstverteilung/erstvert eilung-node.html

3 Singleton, A., Heiermann, A. C., \& Kierans, D. (2016, January 22). International Organization for Migration: Press Releases. Retrieved April 02, 2017, from International Organization for Migration: https://www.iom.int/sites/default/files/country/docs/Germany/Germany-DataBriefing-1Jan2016.pdf

${ }^{4}$ Bayrakli, Enes, and Farid Hafez. European Islamophobia Report 2015. Istanbul: SETA, 2016. 
Germany has been ruled by Christian Democratic Union (CDU) party since 2005. The present chancellor of Germany is Angela Dorothea Merkel who is also the head of CDU. She has been long known for her conservative and quiet politics. The Chancellor of Germany Angela Merkel had persistently held to her party's severity politics in her practices with the Greek credit crisis in the first era of 2015, had taken a trend of international criticism as well as combining domestic support for the interaction between German economic and political authority. Merkel then revitalized her political bequest and managed the supposed 'refugee crisis' in the later months, refashioned her impression as solid, committed, calm and typified in her slogan, Wir schaffen das (transl. We can do it). In a talk show in July 2015, Chancellor Merkel encountered with a Palestinian refugee girl. She explained to refugee girl that she and several others would have to go away from Germany, doesn't matter from how long they have been living here. These encounters had led to criticism, and were even ridiculed within the media and all over society. ${ }^{5}$

In the followed months, Angela Merkel and her coalition of industry and business management had coped to retain Schengen borders exposed, even though Eastern European called to close them. This policy was postured as a loyalty to human rights. In fact, the stake of Chancellor Merkel was to strike a sense of equilibrium amongst the requirements of Germany's powerful export economy with the local and European interest by accepting refugees to a great extent. In the last phases of 2015, the great frequency of immigrants was arriving to Germany persisted, and antirefugee feelings have become a main political objection of German

\footnotetext{
${ }^{5}$ (ibid.).
} 
electors. European unity appears to come apart as to how to cope with the political progress. In Germany, it should also be noted that the racial amount of the Muslims have increased new momentum with mainly Syrians, Afghans and Iraqis looking for shelter in Germany. The degree of Islamophobia has changed a bit and it has progressed more into a legitimate and foremost discourse in established traditional media and Germany's political parties such as the Christian Democratic Union (CDU) party. ${ }^{6}$

Islamophobia carries simultaneously a number of stereotypes and prejudices that move around the amount of the assumed Muslim or Islamist. The consequence of alike historical and societal discourse is an impression that Muslims or Islam are intrinsically dissimilar and thus inconsistent with Germany's local culture. Most notably, this discourse symbolizes summons huge, is that Islamophobia is articulated through culturalized discourse, granting unlawful reason to consider that the hatred or dislike towards Muslims is not an occurrence of racial discrimination, but of a reasonable cultural inconsistency or just particular person biases. In the perspective of its economic and political supremacy of Europe, the native culture of Germany comprehends itself as independent from the social instability of gender, race and class prejudice, when actually class inequalities, sexual biases, gender discrimination, and racial imaginations and dominations are reigning problems in present-day Germany. For this reason, Islamophobia, and the happenings it produces and motivates, are specifically noticeable for the general public which in these examples does not take responsibility for its issues. Thus, Islamophobia impacts on the

\footnotetext{
${ }^{6}$ (ibid.).
} 
German society in two ways by denouncing Muslims and those supposed as Muslim on the one hand, while simultaneously falsely absolving German society from other, continuing social problems. ${ }^{7}$

\section{ISLAMOPHOBIA:}

The Oxford English Dictionary defines Islamophobia as, "a hatred or fear of Islam or Muslims, especially as a political force. "8 The term of Islamophobia was first emerged in United Kingdom in the year 1997 during the Runnymede Trust Report. This report defined the term Islamophobia as "unfounded hostility towards Muslims and therefore fear or dislike of all or most Muslims. "9 Islamophobia or the anti-Muslim sentiment can be defined as "the prejudice against, hatred towards, or fear of the religion of Islam or Muslims." The Organization for Security and Co-operation in Europe (OSCE) and International Helsinki Federation for Human Rights (IHF) defined the term Islamophobia as "intolerance and discrimination against Muslims." Most of the academicians and sociologists have defined this term as a prejudice against the average Muslim because of his or her religion. ${ }^{10}$

The specified hatred of Muslim terrorists or Islamists or any other group connected with Islam or the criticism of Islam could not be taken as Islamophobia. In fact, the academics or experts who denigrate Islam as a religious belief or they raise their voices against the injustices carry out by the dictatorial Muslim governments are known as Islamophobes by

\footnotetext{
7 (ibid.).

${ }^{8}$ Stevenson, Angus. Oxford Dictionary of English. New York: Oxford University Press, $2010,926$.

${ }^{9}$ Morretta, Alison. Islamophobia: Religious Intolerance against Muslims Today. New York: Cavendish Square Publishing LLC, 2016, 6.

10 Arifin, Mohammad Sakib. "Quora." Quora. October 4, 2016. https://www.quora.com/What-exactly-is-Islamophobia (accessed April 6, 2017).
} 
Muslims themselves and in the news media too. The examples of Islamophobia could be taken as the hate speech against Muslims and called them as paedophiles or terrorists, to grab the veil of Muslim women vigorously, to use the firearms against Muslims to frighten them, to burn the Quran in front of Muslims to provoke them, to accuse the Muslims without any proof or to paint any bigotry in the Muslim worships. ${ }^{11}$

\section{ISLAMOPHOBIA IN GERMANY:}

Islamophobia uncover expression in the sphere of the Internet too. Through internet 'Politically Incorrect' (PI-News) believe its PEGIDAlike thought effectively, getting up to one hundred thousand clicks daily. In line with a progressively savvier European-wide network of interconnected right-wing campaigns, Politically Incorrect News has in addition introduced an English description of its web page. Besides this, a collection of online videos has been introduced on the PI-TV. According to their electronic sources, local Politically Incorrect classes are mainly situated in the Western part of Germany. Still prior to PEGIDA develop into a movement, Politically Incorrect News had placed itself as a web portal devoted to "reporting the truth" regarding social ailment in German public by means of hazard of Islam and Muslims as a rallying logic. It is here where the body electorate of Politically Incorrect News and PEGIDA followers most likely finds their shared belief. ${ }^{12}$ A comic style picture was published by PI News on its website of a brown voluptuous female cheerleader which used to wear T-shirt and through poster stated

11 (ibid.).

12 Bayrakli, Enes, and Farid Hafez. European Islamophobia Report 2015. Istanbul: SETA, 2016; "Politically Incorrect." Politically Incorrect. January 7, 2016. https://www.pi-news.net/2016/01/rapefugees-vorlage-zum-download/ (accessed April 9, 2017). 
"Islamophobic but sexy" and "Maria instead of Sharia." Also, her bikini stated "Burka Free Zone., 13

In addition, Politically Incorrect News posted a recommendation at the conclusion of their homepage which stated, "This blog encourage a well-built and protected Israel and encourages its virtues." In that consequence, Political Incorrect-News, more similar to PEGIDA, make use of the help of the state of Israel and its politics in just to shun allegation of racial discrimination. As an alternative of racial discrimination, it shows the dream horror of a 'Clash of Civilizations' as a truth, which in turn for them widen from state of Israel to Germany with the 'Muslim' as the eventual risk. Imagining this steadiness among PEGIDA and web activities such as Politically Incorrect News, and might be yet for the $57 \%$ of the people in a survey by Bertelsmann who apparently sense in danger by Islam/Muslim, permissive sexualized pictures of females, vague assert of sexual and femininity fairness, and incredibly specific patriotic ties appear to all be most important features of a community and politicized Islamophobia in the year $2015 .{ }^{14}$

Diyanet İşleri Türk İslam Birliği (transl. Turkish Islamic Union for Religious Affairs) DITIB is considered to be prime depiction of Islam and Muslim population in Germany and manages the greater part of mosques there. DITIB joined data of all the aforesaid 'minor interpellations', as

\footnotetext{
${ }^{13}$ Alkan, Sena. April 1, 2016.

https://www.dailysabah.com/politics/2016/04/02/islamophobia-skyrockets-in-europesince-charlie-hebdo-attack-report-says (accessed April 7, 2017); Kimminich, Eva. "About Grounding, Courting and Truthifying: Conspiratorial Fragments and Patterns of Social Construction of Reality in Rhetoric, Media and Images." Lexia Journal of Semiotics (2016): 35-53.

14 Bayrakli, Enes, and Farid Hafez. European Islamophobia Report 2015. Istanbul: SETA, 2016.
} 
well as statistics of law enforcement agencies, also information specified to them from their representatives of mosques and their employees. Twelve attacks on mosques were reported in the year 2013, but next two years had shown more attacks on mosque i.e. seventy three in the year 2014 and seventy seven in the year 2015. These crimes involved verbal abuse, vandalism as well as physical attacks on people. ${ }^{15}$

A loud question arose on the headscarf has been taking place as Muslim women highly developed themselves into the German societies of upper and middle class. In numerous spheres it has been debated for long period as a sign of chauvinist subjugation, of political radicalism, or just Islamism, with a core logic of unsuitability with the norms of Germany. Same is the problem for the head covering in community state organizations like educational or legal institutions and the police. Muslim Women wearing a headscarf had been disqualified from all three circles based on a number of disputes about neutrality (while symbolizing the state), ideological inspiration and religious symbolism. ${ }^{16}$

In Germany, the headscarf was started to debate legally and in public when a Muslim woman Fereshta Ludin took the initiative and went to Federal Constitution Court. Due to her headscarf, she had been rejected for the occupation of being a teacher in Baden-Wurttemberg. On this issue, the Federal Constitutional Court had given the judicial rule return to the federal states in 2003 and till March 2015, this issue remained unresolved on a national scale. But on March 2015, the Federal Constitutional Court gave the power to schools to decide that whether headscarf must be allowed for female teachers or not. So if school

\footnotetext{
15 (ibid.).

16 (ibid.).
} 
administration thinks that headscarf is a threat to the school, then they might impose a ban on the headscarf. The response of this newly announced regulation has been mixed, varied extremely and it could take long interval to view the effect of this new course of action due to the dissimilar laws of federal school that have in place yet. The federal states of Berlin and Bremen have prohibited any religious figure in schools, eight federal states had not made any laws regarding the headscarf yet and the states of Baden-Wurttemberg, Bavaria and Hessen would perhaps take dispute with the new directness to spiritual symbolism. The year 2015 considered to be the important year in this regard when working women pointed out headscarf ban as discrimination and brought the case of headscarf not only in the court but also made it a public issue and forced the law making agency to think over it. For instance, the state of North Rhine-Westphalia has altered its federal law and overthrew the common headscarf ban in 2015 . $^{17}$

On June 03, 2015, the debate of headscarf was again started in Berlin, when a young female law student Betul Ulusoy was put on hold after the preliminary receiving of her submitted application without a picture. Later on, she updated the incident about her discrimination on the social networking website i.e. Facebook and the issue spread rapidly. Public interest was generated because she had applied for job at Bezirksamt Neukolln (district office of Neukolln), a region of Berlin which is widely known as the hub of the Arab-Turkish parallel society. Also, notorious Islamophobic agitator Heinz Buschkowsky was formerly

\footnotetext{
17 Deggerich, Markus, Jan Friedmann, and Dietmar Hipp. Spiegel Online. March 21, 2015. http://www.spiegel.de/spiegel/print/d-132696516.html (accessed April 7, 2017).
} 
The Scholar Islamic Academic Research Journal

Vol. 5, No. 2 || July -December 2019 || P. 164-189

https://doi.org/10.29370/siarj/issue8ar15

administrator of this district. The district office that imposed headscarf ban on Ulusoy was not a juridical domain but in fact a public administrative office. The imposed ban on Ulusoy was not on merit but rather a remainder in the native organizational culture of Heinz Buschkowsky's bequest. The district office, on the other hand, accused Ulusoy of intentionally making and exploiting a media scandal against them. $^{18}$

Even though, Ulusoy was lastly offered a job in another public organization in Berlin. But the situation for young Muslim female law students who wear headscarf stayed unresolved. Even though the state has the obligation to teach the female youth students, they would ultimately deal the norms of neutrality which is still required for legal posts and where an individual represents the nation, for instance courtroom. This intended that female youth who wear headscarf are well-informed to become lawyers, whereas the possibilities of them submit to all legal developmental experiences are restricted because of their visible headscarf. A gendered bias is visible towards religious Muslim females who cover with headscarves. On the other hand, religious Muslim males would be capable to do job in any public organization in Germany. So the Muslim females are not being allowed to do work even after having obtained the expensive and time-consuming education by the government. $^{19}$

18

Müller-Neuhof, Jost. Spiegel Online. July 18, 2015. http://www.tagesspiegel.de/berlin/der-fall-betuel-ulusoy-in-berlin-neukoellndroht-neuer-aerger-ums-kopftuch/12073570.html (accessed April 8, 2017).

19 Grunert, Marlene. Wolters Kluwer: Study \& Referral. February 24, 2014. http://www.lto.de/recht/studium-referendariat/s/referendariat-kopftuch-verbotneutralitaetsgesetz/ (accessed April 9, 2017). 
In 2015, the incident of train station on the New Year's Eve in the city of Koln took the debate to another peak. As celebrators were returning to their houses through the train station, women of different age groups found themselves surrounded by an anonymous group of men. They robbed several hundred women while sexually harassed them and even two ladies were raped. For several days, the attacks were not mentioned by the police as well as in the media. After that, when the sufferers of the incident started to protest, the media also initiated to focus on the attacks. This event has inflamed Islamophobic criticism and it could likely to update the legislation in Germany in the future. ${ }^{20}$

Till the mid of January, news had appeared in the local German and international media that 1,000 males from the origins of North African and Arab were involved. The figures informed by the media were differing in contrast to the police statements which reported a group of 3 to 20 men, ${ }^{21}$ without any solid proof about the origin of the committers. Around 400 complaints were lodged to the police of Koln city. The other cities of Germany i.e. Dusseldorf, Hamburg, Frankfurt and Stuttgart also took notice. On January 09, 31 suspected people were identified which included citizens of Germany, America, one from Serbia and 18 refugees from the Middle Eastern countries. The Mayor of Koln city i.e. Henriette Reker, who was wounded during her political campaign for her positive stance

20 Lalami, Laila. The Nation Company LLC: Article. March 10, 2016. https://www.thenation.com/article/who-is-to-blame-for-the-cologne-sex-attacks/ (accessed April 9, 2017).

21 (ibid.); Yaghoobifarah, Hengameh. taz.de: Society. January 6, 2016. http://m.taz.de/Gewalt-gegen-Frauen/!5263311;m/ (accessed April 9, 2017). 
towards refugees, gave a statement that there was no clear indication of the identities of the offenders. ${ }^{22}$

In the course of first week, the press in Germany was criticized for not depicting 'the truth' regarding the happenings instantly, but rather avoiding it due to fright of aggravating anti-refugee feelings. The media was also criticized for the racist depiction of the event in a sensationalized way. ${ }^{23}$ In the mid of January, a weekly magazine of Germany i.e. Focus published an image on its cover page. The photo depicted a naked white woman figure whose body was contaminated with black muddy handprints along with half open mouth. Her body was covered with captions i.e. Frauen klagen an Nach den Sex-Attacken von Migraten: Sind wir noch tolerant oder schon blind? transl. Women complain. After the Sex Attacks of Migrants: Are we still tolerant or blind already? ${ }^{24}$ Also, a newspaper of Germany i.e. Süddeutsche Zeitung published a psychologist's interview on the "mentality" of Arab men. The interview was illustrated with an image of a black hand holding out between a pair of white legs. ${ }^{25}$

In Germany, the situation for females who have been sufferers of rape is disastrous. Barely a crime in Germany is penalized as seldom as rape. According to a research by TERRE DES FEMME in 2014, there

${ }^{22}$ Bayrakli, Enes, and Farid Hafez. European Islamophobia Report 2015. Istanbul: SETA, 2016.

${ }^{23}$ (ibid.).

24 FOCUS Online. "FOCUS Online: Fotos." FOCUS Online. January 2016. http://p5.focus.de/img/fotos/origs5197352/1942309070-w1280-h480-o-q72p4/focus02-2016.jpg (accessed April 9, 2017); Lalami, Laila. The Nation Company LLC: Article. March 10, 2016. https://www.thenation.com/article/who-is-to-blame-for-the-cologne-sex-attacks/ 25 (ibid.). (accessed April 9, 2017). 
have been almost 160,000 rapes per year in Germany. This shows more than 438 rapes per day and approximately 1,000 convictions annually. The probability for a male to be held accountable and offended for rape is thus less than one percent in Germany. ${ }^{26}$ Also in the German festivities of Oktoberfest, every day comes with an indication of rape. ${ }^{27}$ Unlike these figures, on January 07, 2016, PI News posted an image on its website regarding the refugees welcoming claim. Götz Wiedenroth, a German cartoonist created an image with the text, "Rapefugees Not Welcome" !Stay Away! The image was created due to the Koln train incident. ${ }^{28}$

In the last two quarters of 2015, the dread of an imported antiSemitism intensified, due to immigrants from mainly Muslim-majority countries and was debated in the public. Much of the published content as well as debates revolved around a supposed anti-Semitic and anti-Israel criticism that was claimed to form part of socialization in areas such as Syria and Iraq. Jewish organizations and figures as well as democratic ideals of Germany were supposed to be threatened by the new asylum seeker population. $^{29}$

26 Terre des Femmes. "Terre des Femmes." Terre des Femmes. n.d. http://www.frauenrechte.de/online/index.php/themen-und-aktionen/haeuslicheund-sexualisierte-gewalt/aktuelles/archiv/1640-erfolg-bundesjustizministeriumwill-vergewaltigungsparagraf-177-stgb-verschaerfen (accessed April 9, 2017).

27 Hörmann, Andi. "Germany Radio." Germany Radio. September 22, 2014. http://www.deutschlandfunkkultur.de/oktoberfest-bier-promille-undvergewaltigungen.2156.de.html?dram:article_id=298239 (accessed April 9, 2017).

28 "Politically Incorrect." Politically Incorrect. January 7, 2016. https://www.pinews.net/2016/01/rapefugees-vorlage-zum-download/ (accessed April 9, 2017).

29 Brenner, Michael. "Süddeutsche Zeitung GmbH: Culture." Süddeutsche Zeitung GmbH. September 20, 2015. http://www.sueddeutsche.de/kultur/debattebringen-die-fluechtlinge-mehr-antisemitismus-nach-deutschland-1.2655933 (accessed April 9, 2017). 
The Scholar Islamic Academic Research Journal

Vol. 5, No. 2 || July -December 2019 || P. 164-189

https://doi.org/10.29370/siarj/issue8ar15

In November 2015, the member of the Christian Democratic Union (CDU) Julia Klockner in North Rhine-Westphalia, suggested initiating a contract between immigrants and German state for the next party congress in mid of December entitled, "Integrationsplan" (A plan for integration). The proposals given by Julia Klockner were welcomed and included a cut in social welfare and the likelihood of the cancellation of the right to stay, if the given norms have treated with disrespect. This also involved the receipt of gender equality, homosexuality and the German legitimate ascendancy above Sharia law. Also, the backup for the reason for existence of Israel as well as the refusal of any sort of anti-Semitism. ${ }^{30}$ This latter feature of anti-Semitism involved any form of anti-Semitism which could be understood in the conclusion of many events, for instance the Israel-Gaza conflict in 2014. During this war, Angela Merkel stated in public that "the recent alleged critique against the politics of the state of Israel uttered on pro-Palestinian demonstrations, were nothing but the expression of hatred against Jews [...]. ",31

\section{PEGIDA}

The attitude of Islamophobia has been mirrored in Germany with the rise of anti-Muslim movement i.e. Patriotische Europäer gegen die Islamisierung des Abendlandes (PEGIDA). In English, Patriotic Europeans against the Islamisation of the West (Occident). This far-right anti-Islam movement had come into existence in the year 2014 and this

$30 \quad$ "Spiegel Online: Politics." Spiegel Online. February 14, 2016. http://www.spiegel.de/politik/deutschland/julia- kloeckner-bekraeftigt-cduintegrationsplan-fuer-fluechtlinge-a-1077360.html (accessed April 9, 2017).

${ }^{31}$ Press and Information Office of the Federal Government. Press and Information Office of the Federal Government. September 14, 2014. https://www.bundesregierung.de/Content/DE/Rede/2014/09/2014-09-14-merkelkundgebung-judenhass.html (accessed April 9, 2017). 
The Scholar Islamic Academic Research Journal

Vol. 5, No. 2 || July -December 2019 || P. 164-189

https://doi.org/10.29370/siarj/issue8ar15

conforms to the discourse of anti-Muslim racism. ${ }^{32}$ The movement was begun on October 10, 2014. Lutz Bachmann, an owner of a photography studio in the territory of Kesselsdorf, Germany, uploaded a video on the social networking website i.e. YouTube. This video depicted the rally of Dresden in the support of Kurdish fighters combating Islamic State. After one day, Bachmann created a social networking website Facebook group entitled, "Peaceful Europeans against the Islamization of the West." This social networking service eventually turned into the movement of PEGIDA. ${ }^{33}$ PEGIDA has been exploited the anti-immigrant agenda and this movement has gained its popularity not only in Germany but also in other parts of the world. This movement has held the rallies against the 'Islamization', immigrants and open-door refugee strategy of German Chancellor Angela Merkel. ${ }^{34}$

The second rally of the movement was held in the month of October 2014 and more than 500 Dresdeners were gathered in the rally against the "religious war" on German territory. Dresden is the birthplace of PEGIDA movement. The organizers of PEGIDA had planned to protest in Dresden on every Monday evening till the political system does not give attention to the problem. One of the organizers i.e. Lutz Bachmann said, "With understanding for all the misery and horror of the warlike confrontations in all the war-torn areas of the earth, we Germans and

32 Bayrakli, Enes, and Farid Hafez. European Islamophobia Report 2015. Istanbul: SETA, 2016.

${ }^{33}$ Popp, Maximilian, and Andreas Wassermann. Spiegel Online: International. January 12, 2015. http://www.spiegel.de/international/germany/origins-of-german-antimuslim-group-pegida-a-1012522.html (accessed March 22, 2017).

34 Autonomous Nonprofit Organization "TV-Novosti". October 16, 2016. https://www.rt.com/news/362965-pegida-dresden-anniversary-rally/ (accessed April 11, 2017). 
The Scholar Islamic Academic Research Journal

Vol. 5, No. 2 || July -December 2019 || P. 164-189

https://doi.org/10.29370/siarj/issue8ar15

Europeans cannot be the reception center of the world, and bring these wars to our own streets, no matter how beautiful our land is." He gave emphasis to the denunciation of violence, from whatever way it may come. $^{35}$

In the month of December 2014, some 10,000 people took part in the PEGIDA's weekly demonstration in the city of Dresden. ${ }^{36}$ The associated demonstrations of PEGIDA had sprung up in 2014 in the several cities of Germany which included Legida in Leipzig, ${ }^{37}$ Bargida in Berlin, ${ }^{38}$ Magida in Magdeburg, ${ }^{39}$ Sügida in Suhl, ${ }^{40}$ Kagida in Kassel, Bogida in Bonn, Wügida in Würzburg, Dügida in Düsseldorf ${ }^{41}$ and Fragida in Frankfurt. ${ }^{42}$

Bodissey, Baron. Gates of Vienna: PEGIDA. October 28, 2014. http://gatesofvienna.net/2014/10/patriotic-europeans-against-the-islamization-ofthe-west/ (accessed March 10, 2017).

36 Le Temps SA. Le Temps SA: World. December 10, 2014. https://www.letemps.ch/monde/2014/12/10/patriotes-allemands-se-mobilisentcontre-immigration (accessed March 20, 2017).

Euronews.

Euronews.

January

12 , 2016. https://www.euronews.com/2016/01/12/merkel-needs-to-go-chant-legidaprotesters-in-march-through-leipzig (accessed October 25, 2017).

Lane, Oliver JJ. Breitbart: National Security. January 20, 2015. http://www.breitbart.com/national-security/2015/01/20/pegida-rallies-takeplace-across-germany-despite-terrorism-threat/ (accessed March 31, 2017). ZEIT ONLINE. ZEIT ONLINE. February 19 , https://blog.zeit.de/stoerungsmelder/2015/02/19/magida-zwischen-afdhooligans-und-neonazis_18675 (accessed June 12, 2017).

40 Media Group Thuringia. Media Group Thuringia. January 1, 2015. https://www.thueringer-allgemeine.de/politik/suegida-eintausenddemonstranten-marschieren-durch-suhl-id220652851.html (accessed July 25, 2017).

Knight,

Ben.

February

23 ,

2015. https://www.theguardian.com/world/2015/feb/23/pegida-head-lutz-bachmannreinstated-hitler-moustache-photo (accessed October 15, 2017).

42 Gedziorowski, Lukas. Journal Frankfurt: Politics. December 15, 2014. https://www.journal-frankfurt.de/journal_news/Politik-10/AntiIslamisierungsbewegung-kommt-nach-Frankfurt-Pegida-wird-Fragida23358.html (accessed March 30, 2017). 
The Scholar Islamic Academic Research Journal

Vol. 5, No. 2 || July -December 2019 || P. 164-189

https://doi.org/10.29370/siarj/issue8ar15

On January 12, 2015, more than 25,000 people gathered in the weekly demonstration of PEGIDA in Dresden. This was the biggest ever turnout of this movement. The rally was held right after the Paris attacks, in which 17 people were died, including ten journalists from the satirical magazine of France i.e. Charlie Hebdo. This was the first time when the German flags were also joined by their neighboring nation French flags in "solidarity" with the victims of the attacks. The crowd was shouting "Wir sind das Volk!" transl. "We are the people” and Lügenpresse, halt die Fresse transl. "Shut up, lying press. " 43 One senior citizen shouted “I'm a pensioner. I only get a small pension but I have to pay for all these people (asylum seekers). No-one asked me!" One banner proclaimed "No sharia law in Europe!"44 The phrase "Lügenpresse" (transl. "lying press"), was used by the PEGIDA demonstrators who claim to promote their views

${ }^{43}$ Brady, Kate. Deutsche Welle: News. January 12, 2015. http://www.dw.com/en/recordturnout-at-dresden-pegida-rally-sees-more-than-25000-march/a-18186820 (accessed March 25, 2017); Chandler, Adam. The Atlantic Monthly Group: Global. January 14, 2015. https://www.theatlantic.com/international/archive/2015/01/the-worst-germanword-of-the-year/384493/ (accessed April 03, 2017); Hill, Jenny. BBC News: Europe. December 16, 2014. http://www.bbc.com/news/world-europe-30478321 (accessed March 25, 2017); Popp, Maximilian, and Andreas Wassermann. Spiegel Online: International. January 12, 2015. http://www.spiegel.de/international/germany/origins-of-german-anti-muslimgroup-pegida-a-1012522.html (accessed March 22, 2017); The Local. The Local. January 13, 2015. https://www.thelocal.de/20150113/pegidas-favorite-wordbecomes-non-word-of-the-year (accessed April 03, 2017); Wagstyl, Stefan. The Financial Times Ltd., Germany. January 13, 2015. https://www.ft.com/content/44ae4fce-9aaf-11e4-86c2-00144feabdc0 (accessed March 22, 2017).

${ }^{44}$ Hill, Jenny. BBC News: Europe. December 16, 2014. http://www.bbc.com/news/worldeurope-30478321 (accessed March 25, 2017). 
The Scholar Islamic Academic Research Journal

Vol. 5, No. 2 || July -December 2019 || P. 164-189

https://doi.org/10.29370/siarj/issue8ar15

about the world and they called on the media to "tell the truth" about what refugees are doing to Germany. ${ }^{45}$

\section{PEGIDA'S FOUNDER LUTZ BACHMANN}

The founder of PEGIDA i.e. Lutz Bachmann was a chef who turned into a graphic designer. He has confessed to past criminal verdicts which included for drug-dealing. He was arrested on the charges of armed burglary. He has also admitted that he had spent two years in prison. ${ }^{46} \mathrm{On}$ January 21, 2015, the founder of PEGIDA Lutz Bachmann uploaded a photograph on its social networking Facebook page by styling himself as Hitler. After a session at his hairdresser's, complete with Adolf Hitler hairstyle dyed black and separated on the right, and a toothbrush moustache. The image was posted with the line "he's back", after a bestselling 2012 novel about Adolf Hitler, Er ist wieder da (transl. He's Back), by author Timur Vermes. ${ }^{47}$ Bachmann deleted his status soon after being contacted by the newspaper i.e. Dresden Morgenpost. Lutz Bachmann had called asylum seekers as "cattle", "scumbags" and "animals" in the welfare offices. After that, he stepped back from his role

45 Chandler, Adam. The Atlantic Monthly Group: Global. January 14, 2015. https://www.theatlantic.com/international/archive/2015/01/the-worst-germanword-of-the-year/384493/ (accessed April 03, 2017); The Local. The Local. January 13, 2015. https://www.thelocal.de/20150113/pegidas-favorite-wordbecomes-non-word-of-the-year (accessed April 03, 2017).

${ }^{46}$ Hill, Jenny. BBC News: Europe. December 16, 2014. http://www.bbc.com/news/worldeurope-30478321 (accessed March 25, 2017); Le Temps SA. Le Temps SA: World. $\quad$ December $10, \quad 2014$. https://www.letemps.ch/monde/2014/12/10/patriotes-allemands-se-mobilisentcontre-immigration (accessed March 20, 2017).

47 Connolly, Kate. Guardian News and Media Limited: Books. February 5, 2013. https://www.theguardian.com/world/2013/feb/05/adolf-hitler-novel-germanbestseller (accessed March 29, 2017); Connolly, Kate. "Photograph of Germany's Pegida Leader Styled as Adolf Hitler Goes Viral." Guardian News \& Media Limited, https://www.theguardian.com/world/2015/jan/21/pegida-leaderstyled-adolf-hitler-lutz-bachmann-german-islamist-terrorists-facebook. 
The Scholar Islamic Academic Research Journal

Vol. 5, No. 2 || July -December 2019 || P. 164-189

https://doi.org/10.29370/siarj/issue8ar15

in the group and resigned as the chairman of PEGIDA. ${ }^{48}$ After a month later, Lutz Bachmann was re-elected as the chairman of PEGIDA. He was elected by the organization's leadership committee on February 22, $2015^{49}$

\section{FIRST ANNIVERSARY OF PEGIDA}

On the first anniversary of PEGIDA in October 2015, around 20,000 people were gathered in the demonstration at the city of Dresden. The movement of PEGIDA observes Muslims as more sexist, homophobic, criminal, and terrorist as compared to white Germans. The discourse of PEGIDA attempts to defuse any accusation of racial discrimination through the optimistic elicitation of Judeo-Christian values. They occasionally expressed their agenda by the flapping of flags of Israel or inviting speeches by the Israeli narrators. PEGIDA also asserts that Muslims and immigrants cause danger to the economy of Germany and welfare state authorizing free rides in an already risky economy from which many followers of PEGIDA consider themselves to be neglected or left out. ${ }^{50}$ The representatives of PEGIDA have persistently linked their strategy appeal to the traditional discourse of Germany. In this way, PEGIDA almost single-handedly questions the peripheral status of Islamophobia, trying to postulate it instead in the conventional German

48 (Ibid.); Deutsche Welle. Deutsche Welle: News. January 21, 2015. http://www.dw.com/en/pegida-founder-bachmann-quits-after-hitler-mustachephoto/a-18207351 (accessed March 27, 2017); Goulard, Hortense. Politico SPRL: Article. July 19, 2016. http://www.politico.eu/article/germans-anti-islampegida-movement-launches-political-party/ (accessed March 29, 2017);

49 Knight, $\quad$ Ben. $\quad$ February 2015. https://www.theguardian.com/world/2015/feb/23/pegida-head-lutz-bachmannreinstated-hitler-moustache-photo (accessed October 15, 2017).

50 Bayrakli, Enes, and Farid Hafez. European Islamophobia Report 2015. Istanbul: SETA, 2016. 
society. So due to the hindrance of being termed as a vulgar mass movement beside with their consistent sensation of not being taken seriously, some demonstrators of PEGIDA marched gallows designed for the German Chancellor Angela Merkel as well as Vice Chancellor of Germany i.e. Sigmar Gabriel, in the first anniversary demonstration. ${ }^{51}$

\section{SECOND ANNIVERSARY OF PEGIDA}

In October 2016, supporters of the PEGIDA movement gathered in the city of Dresden to mark the second anniversary. According to Mitteldeutscher Rundfunk (transl. Central German Broadcasting) MDR, around 5,000 demonstrators were present at the rally. But the statistical research group of Germany i.e. Durchgezahlt stated the high figure as 6,500-8,500. The supporters protested against the immigrant policy of German Chancellor Angela Merkel, also what they see as involuntary multiculturalism and the continual Islamization of Europe. ${ }^{52}$

The demonstrators expressed their views as:

- 'You have a million foreigners every year. They don't speak the German language, they do not accept our culture, they have very basic or no education or no professional skills."

- "We have no use for them. We have our own German problems."

- "We have more rapes, we have more criminality, we have more violence that we didn't have before. ",53

\footnotetext{
$51 \quad$ (ibid.); $\quad$ Spiegel Online: Politics. $\quad$ October $13, \quad 2015$. http://www.spiegel.de/politik/deutschland/pegida-demo-staatsanwaltschaftermittelt-wegen-galgen-a-1057524.html (accessed March 26, 2017).

52 Autonomous Nonprofit Organization "TV-Novosti". October 16, 2016. https://www.rt.com/news/362965-pegida-dresden-anniversary-rally/ (accessed 53 (ibid.). April 11, 2017).
} 
The Scholar Islamic Academic Research Journal

Vol. 5, No. 2 || July -December 2019 || P. 164-189

https://doi.org/10.29370/siarj/issue8ar15

PEGIDA, GERMAN SOCIETY AND REFUGEES

In Germany, violent attacks have been progressively increased on refugees. Racially prejudiced agitation is also on the rise, whether on the social networking website or on the highway. The online theatricals also lead to actual attacks on immigrants and their shelters. In the year 2014, 247 violent attacks have been counted on refugee accommodations. These also include 36 detention centers that could be reported. Moreover, 81 attacks on individuals were also counted. According to BKA (Bundeskriminalamt) transl. Federal Criminal Police Office the number of violence and propaganda accusations had increased by more than double as compared to the previous year. The attacks are regionally mostly spread. Additionally Berlin, North RhineWestphalia and Saxony as the top runners, most of the federal states are represented several times. ${ }^{54}$ A survey was conducted by YouGov on the part of ZEIT ONLINE in which $49 \%$ of the respondents expressed that they had an understanding of the ongoing demonstrations in Germany. This sustains sympathy for the demonstrators of the anti-Islamic movements. According to the survey, $73 \%$ of the federal residents were concerned about the fear of radical Islamists in Germany. ${ }^{55}$

Another survey was conducted in Germany by the Bertelsmann Foundation before the Paris attacks on the satirical magazine of France i.e. Charlie Hebdo. According to the survey, $57 \%$ of German considers Islam

\footnotetext{
54 Amadeo Antonio Foundation. Amadeo Antonio Foundation. December 14, 2014. https://www.mut-gegen-rechte-gewalt.de/news/meldung/rechte-hetze-gegenfluechtlinge-eine-chronik-der-gewalt-2014-03 (accessed April 02, 2017).

55 Zeit Online. Zeit Online: Politics. December 15, 2014. http://www.zeit.de/politik/deutschland/2014-12/islam-pegida-fluechtlingedeutschland-umfrage (accessed April 03, 2017).
} 
as a threat. Also, $40 \%$ of the German population feels like "strangers in their own country" and 24\% would favor Muslims to fully ban immigration to Germany. In 2014, 61\% of German population still believes that Islam does not appropriate into the Western world. ${ }^{56}$ The immigrants and their shelters have been strongly affected in the first quarter of 2015 by the racist violence. The tenacious prejudiced protests against the immigrants and their shelters, the rallies of PEGIDA movement and its detachment in other federal states and the lack of reorganized lodging facilities as well as the debate that presents asylum seekers as a problem rather than a proactive member of the society, they all contribute to the fact that there are no harmless places for the refugees in the German territory. ${ }^{57}$

During the course of the year 2015, the immigrants predominantly from the Muslim countries i.e. Syria, Iraq and Afghanistan had led to verbal, material and physical attacks throughout the Germany. ${ }^{58}$ Till October 2015, around 850 attacks have been counted on the refugee shelters and in the third quarter of the year, a total of 13 people have been injured in these violent offenses. ${ }^{59}$ On January 8, 2015, a recently opened refugee lodging was attacked with the bottles in Kopenick, Berlin city.

\footnotetext{
56 Lobbert, Raoul. Die Zeit. January 4015. http://www.zeit.de/gesellschaft/zeitgeschehen/2015-01/islam-pegidaislamfeindlichkeit-religionsmonitor (accessed April 03, 2017).

$57 \quad$ ReachOut: Home. April 27, 2015. http://www.reachoutberlin.de/de/content/unabh\%C3\%A4ngige-opferberatungsprojektever\%C3\%B6ffentlichen-gemeinsame-statistik-f\%C3\%BCr-2014 (accessed March 30, 2017).

58 Bayrakli, Enes, and Farid Hafez. European Islamophobia Report 2015. Istanbul: SETA, 2016.

59 (ibid.); German Bundestag. German Bundestag: Interior. November 16, 2015. https://www.bundestag.de/presse/hib/2015-11/-/395984 (accessed April 02, 2017).
} 
The attack was occurred by shouting "we torch you all off." These types of attacks create huge threat situations. The affected people all over the Germany had reported that they do not trust the road any more. ${ }^{60}$

In the year 2015, 146 violent attacks have been counted on the refugees and their accommodations. These also include the counseling centers in the German states of Berlin and North Rhine-Westphalia (NRW) that could be reported. The attacks were attempted in the form of firefights, bodily injuries, pyrotechnics, stone throwing or explosives. The top three states where mostly attacks were occurred on the localities of refugees were registered in Saxony, North Rhine-Westphalia and Berlin respectively. ${ }^{61}$ In 2015, most of the incidents which were recorded as Islamophobic violence in Berlin were occurred in the locality of PEGIDA demonstrations i.e. BarGiDa. Berlin Protest against the Islamization of the West i.e. BarGiDa is the term of the Berlin branch. ${ }^{62}$ Only in Berlin, the greater number of verbal or physical attacks against the Muslims, on the mosques and refugees, were predominantly happened in Berlin's centre i.e. Mitte and on the peripheries of the BarGiDa demonstrations. ${ }^{63}$

In June 2015, with the entrance of a few hundred immigrants, the German town i.e. Freital, Saxony gained media attention due to the

\footnotetext{
$60 \quad$ ReachOut: Home. January $\quad 18, \quad 2015$. http://www.reachoutberlin.de/de/content/demonstration-gedenken-khaled-idris-bahray (accessed April 04, 2017).

61 ReachOut: Home. March 9, 2016. http://www.reachoutberlin.de/de/content/pm-desvbrg-rechts-motivierte-angriffe-im-vergleich-zu-2014-nahezu-verdoppelt (accessed April 04, 2017).

62 Bayrakli, Enes, and Farid Hafez. European Islamophobia Report 2015. Istanbul: SETA, 2016; ReachOut. ReachOut. March 17, 2015. http://www.reachoutberlin.de/de/content/berlin-tiergarten-29 (accessed April 4, 2017).

63 Bayrakli, Enes, and Farid Hafez. European Islamophobia Report 2015. Istanbul: SETA, 2016.
} 
The Scholar Islamic Academic Research Journal

Vol. 5, No. 2 || July -December 2019 || P. 164-189

https://doi.org/10.29370/siarj/issue8ar15

intensity of violence against refugees. The city of Freital had already seen clashes between opponents and supporters of refugee shelters for months. The town also became the part of a stand-off between the Federal Minister of the Interior of Germany Karl Ernst Thomas de Maizière, among others, and 'concerned residents' on the other side, along with supporters by the PEGIDA movement. The main organizers of PEGIDA i.e. Lutz Bachmann and Tatjana Festerling, legislatures of the neo-liberal conservative party AFD Alternative für Deutschland (transl. Alternative for Germany) and the right-wing party NPD Nationaldemokratische Partei Deutschlands (transl. National Democratic Party of Germany). People critical of the anti-refugee feelings were screamed down and vocally harassed to "shut up. "64 Violent fictions such as burning buses with refugees were articulated online and on the social networking website i.e. Facebook page of PEGIDA. ${ }^{65}$

In August 2015, the town of Heidenau in the state of Saxony had seen the mobilization of racist marches. The strongest outbreak of violence occurred on August 21, 2015, when around 1,000 participants marched through the city and finally blocked the road on which 600 immigrants were brought. The conflict erupted in violence when the demonstrators attacked the police. The police was protecting the immigrants on their way into the asylum home. The eruption resulted to 31 injuries of police officers including one of them with severe wounds. The demonstrators had

\footnotetext{
${ }^{64}$ Nasir Husain, Muhammad Shafqatullah

(ibid.).; Zeit Online: Politics. July 7, 2015. http://www.zeit.de/politik/deutschland/201507/freital-buergerversammlung-tumulte (accessed April 04, 2017).

${ }^{65}$ Bayrakli, Enes, and Farid Hafez. European Islamophobia Report 2015. Istanbul: SETA, 2016; Maxwill, Peter. Spiegel Online: Politics. June 25, 2015. http://www.spiegel.de/politik/deutschland/fluechtlingsheim-in-freital-poebelpingpong-im-pegidaland-a-1040544.html (accessed April 4, 2017).
} 
thrown bottles, stones, and bombers in front of a previous hardware store, which was then to be used as an emergency accommodation for the refugees. The dozens of refugees had been able to get the emergency lodging only under the police protection in the town of Heidenau, Saxon. ${ }^{66}$

\section{CONCLUSION}

The study focused on the different Islamophobic events in Germany along with the rise of anti-Islamic and anti-Muslim movement i.e. PEGIDA. A number of protests and demonstrations by PEGIDA and its associations have been discussed in this research work. The study revealed that PEGIDA is responsible not only for the discursive violence but it is also responsible for the interpersonal violence. For illustration, during the demonstrations of PEGIDA in Berlin, the attacks on individuals taken to be 'Muslims' have increased throughout 2015. The continuing arrival of refuge seekers into Germany, the greater number of whom come from primarily Muslim countries, has decided Islamophobia a license to operate under apparently reasonable and sincere concerns around the Muslim 'Other' and Islam obvious. The year 2015 had seen Islamophobia become an indisputable force within the German society. ${ }^{67}$ As half of the German population had an understanding of the ongoing demonstrations in Germany and which sustains sympathy for the demonstrators of the antiIslamic movements. ${ }^{68}$ And the violent attacks have been progressively

66 Meisne, Matthias. Zeit Online: Society. August 22, 2015. http://www.zeit.de/gesellschaft/zeitgeschehen/2015-08/heidenau-fluechtlingeausschreitungen-polizei (accessed April 04, 2017).

67 Bayrakli, Enes, and Farid Hafez. European Islamophobia Report 2015. Istanbul: SETA, 2016.

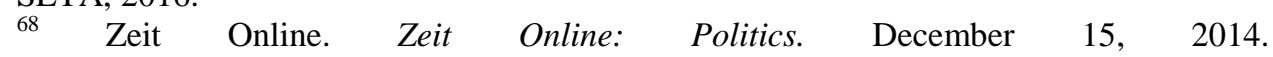
http://www.zeit.de/politik/deutschland/2014-12/islam-pegida-fluechtlingedeutschland-umfrage (accessed April 03, 2017). 
The Scholar Islamic Academic Research Journal

Vol. 5, No. 2 || July -December 2019 || P. 164-189

https://doi.org/10.29370/siarj/issue8ar15

increased on refugees, either on the social networking websites or on

the highway as well as on the refugee accommodations or on their detention centers. ${ }^{69}$ The Syrian, Iraqi and Afghani refugees had been led to verbal, material and physical attacks throughout the Germany and they have been injured in these violent offenses. ${ }^{70}$ Likewise, the greater numbers of verbal or physical attacks against the Muslims and on the mosques were predominantly happened in the peripheries of the BarGiDa demonstrations and the ratio of attacks on DITIB mosques in Germany has also been increased since 2013. ${ }^{71}$ Furthermore, in August 2015, the conflict erupted in violence in Heidenau when the PEGIDA demonstrators blocked the road on which immigrants were brought and marches attacked the police. ${ }^{72}$ So due to the rise of PEGIDA movement and its associations in Germany, the attacks on Muslims, their accommodations or on their worships could be increase in the coming years. The Muslims would feel threaten from the PEGIDA rallies and its demonstrators, and situation could be worse for all the Muslims who are living in Germany.

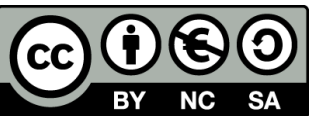

This work is licensed under a Creative Commons

Attribution-NonCommercial-ShareAlike 4.0 International (CC BY-NC-SA 4.0)

69 Amadeo Antonio Foundation. Amadeo Antonio Foundation. December 14, 2014. https://www.mut-gegen-rechte-gewalt.de/news/meldung/rechte-hetze-gegenfluechtlinge-eine-chronik-der-gewalt-2014-03 (accessed April 02, 2017).

70 Bayrakli, Enes, and Farid Hafez. European Islamophobia Report 2015. Istanbul: SETA, 2016; German Bundestag. German Bundestag: Interior. November 16, 2015. https://www.bundestag.de/presse/hib/2015-11/-/395984 (accessed April 02, 2017).

71 Bayrakli, Enes, and Farid Hafez. European Islamophobia Report 2015. Istanbul: SETA, 2016.

${ }^{72}$ Meisne, Matthias. Zeit Online: Society. August 22, 2015 http://www.zeit.de/gesellschaft/zeitgeschehen/2015-08/heidenau-fluechtlingeausschreitungen-polizei (accessed April 04, 2017). 